\title{
Energy Expenditure by Heifers Grazing Crested Wheatgrass of Diminishing Availability
}

\author{
K.M. HAVSTAD AND JOHN C. MALECHEK
}

\begin{abstract}
The daily mean energy expenditure of free-ranging heifers grazing crested wheatgrass rangeland was estimated as 161 $\mathrm{kcal} / \mathrm{kgBW}^{.75} /$ day using the carbon dioxide entry rate technique (CERT). This was $46 \%$ greater than the mean $110 \mathrm{kcal} / \mathrm{kgBW}^{.75} /$ day estimated for stall-fed heifers consuming similar forage. Under laboratory conditions, CERT can provide a mean estimate of energy expenditure that has a standard error of $5 \%$ and a coefficient of variation of $20 \%$.
\end{abstract}

In contrast to the stall-fed animal, the range animal requires additional dietary energy to meet the demands of its free-roaming condition. For sheep on pasture, Young and Corbett (1972) reported a $60-70 \%$ increase in daily energy expenditure above the maintenance costs of penned sheep. Young (1970) and Wallace (1956) have reported $60 \%$ and $50 \%$ increases, respectively, for grazing cattle.

These substantial increases in energy expenditure have several possible origins. Osuji (1974) reviewed the literature on the energy expenditure of the pastured ruminant and suggested that the increased energy costs might be due in part to an increased amount of time spent obtaining food and the locomotion associated with grazing. For example, $40 \%$ of the energy expended by grazing sheep has been attributed to their activities of standing, walking, ruminating and eating as compared to $10 \%$ for a penned animal consuming roughages (Graham 1964). Each hour spent grazing by cattle represents a $2 \%$ increase in daily energy expenditure (Holmes et al. 1978). Cattle on crested wheatgrass rangeland typically spend 7.7 to 10 hours daily grazing (Scarnecchia 1980). Additionally, the daily time spent grazing increases as the quantity of available forage declines (Nastis 1979), although cattle seldom graze longer than 13 hours a day, irrespective of forage conditions or availability (Arnold and Dudzinski 1978).

The energetic cost of travel on level terrain has been estimated as 0.45 to $0.78 \mathrm{kcal} / \mathrm{kgBW} / \mathrm{km}$ (Blaxter 1962, Graham 1964, Osuji 1974). Although travel involves a negligible expense for the stallfed animal, various researchers have reported traveling distances of 5 to $12 \mathrm{~km}$ a day for cattle on western U.S. ranges (Dwyer 1961, Herbel and Nelson 1966, Malechek and Smith 1976). Thus, travel could easily add $10 \%$ to the daily energy expenditure of the grazing animal. Additional unknown stress-related factors also may contribute to increases in energy expenditure when animals are forced to search for food under conditions of scarcity. The extent to which

\footnotetext{
Authors are assistant professor, Department of Animal and Range Science, Montana State University, Bozeman; and professor, Department of Range Science, Utah State University, Logan. At the time of this research, Havstad was research assistant, Range Science Department, Utah State University.

This paper was approved by the Director, Utah Agr. Exp. Sta. as Journal Paper No. 2727.

Manuscript received in 1980.
}

free-roaming conditions increase the energy expended by the grazing ruminant warrants a close examination of factors affecting energy expenditure. This knowledge would be important in planning grazing management systems, particularly those that have as their objective uniform grazing, which may tend to stress animals. Thus, the purpose of this study was to mea sure the energy expenditure of grazing heifers at several different levels of available forage, and to compare these quantities to the energy expended by similar stall-fed animals consuming a diet of similar quality and quantity.

Precise estimates of energy expended by the free-roaming animal are limited by available technology. Techniques for indirect estimation of energy expenditure include time budget analysis and food intake balance and energy balance models. These techniques are either still being tested or may be limited by numerous assumptions involved in their application. For direct estimation of energy expenditure, accepted and applicable methods of indirect calorimetry include respiratory gas exchange (Young et al. 1975), heart rate and respiratory rate estimation (Yamamoto et al. 1979), and the carbon dioxide entry rate technique (CERT) (Whitelaw et al. 1972). Typically, gas exchange methods require fistulation of the trachea, and the associated equipment required for gas measurement is cumbersome. Young and Corbett (1972) reported that this technique estimated energy expenditure with a standard mean error of $12 \%$. The heart rate measurement technique has been used with increasing frequency during recent years. Each animal's heart rate must be calibrated with their oxygen consumption, and this relationship varies with cardiac stroke volume and responses to emotional factors (Brockway 1978). Yamamoto et al. (1979) reported a mean standard error of $16 \%$ when heart rate was used to estimate energy expenditure of cattle. CERT has been suggested as the most suitable measurement for estimating energy expenditure of the grazing ruminant (Webster 1972). However, mean standard errors of 7 to $20 \%$ for energy expenditure estimates have been reported by users of CERT (Young et al. 1969, Whitelaw et al. 1972). Methodology is apparently best chosen on the basis of availability and suitability of a particular technique and its associated equipment to conditions at hand rather than upon attainment of a prescribed limit of statistical reliability. Due to the availability of the necessary equipment, CERT technology was selected for the experiment reported here.

\section{Methods}

\section{Field Study}

A field experiment was conducted during 1979 and a laboratory experiment during 1980. The former was conducted at the Tintic Valley Cooperative Research Station, Juab County, Utah, a site typical of the foothill rangelands of the eastern Great Basin. The 
research station has an average annual precipitation of $330 \mathrm{~mm}$ with $30 \%$ as winter snow and the remainder spread erratically as rain throughout the other three seasons. The study area was a 28-ha pasture, representative of a semidesert loam range site. The pasture, with a $2 \%$ slope, had been seeded to crested wheatgrass (Agropyron cristatum) in 1949.

During June 1979, four 305-kg yearling Angus heifers were placed on the study area. Following a 3-week preliminary period, five 10-day trials were conducted at regular intervals over the course of the next 75 days. Each period included two 24-hour estimations of $\mathrm{CO}_{2}$ entry rate with each animal. The quantity of forage available during each period was determined by the ocular weight-estimate technique (Pechanec and Pickford 1937) applied to 40 rand omly located $1-\mathrm{m}^{2}$ circular plots. The level of available forage was systematically reduced between each trial by put-andtake grazing of 30 additional animals.

CERT methodology has been described in detail by Young (1970). Briefly, this technique utilizes the principles of isotope dilution (Lifson and McClintock 1966) to estimate the daily $\mathrm{CO}_{2}$ turnover by an animal. The isotope, ${ }^{14} \mathrm{C}$, was subcutaneously infused as $\mathrm{HaH}^{14} \mathrm{CO}_{3}$ (prepared in a $0.15 \mathrm{M} \mathrm{NaCl}$ and $0.01 \mathrm{M}$ $\mathrm{NaHCO}_{3}$ solution) at a calibrated constant rate of $50 \mathrm{nCi} / \mathrm{min}$ for $24 \mathrm{hr}$.

A portable battery-powered Harvard ${ }^{1}$ infusion pump was enclosed in a canvas pouch fastened over the animal's withers. The isotope solution was infused through a $50 \mathrm{~mm}$ Teflon catheter (with a 16 gauge insertion needle) placed subcutaneously in the heifer's right shoulder. A $3.8 \mathrm{~mm}$ (I.E.) (24 French size) Foley catheter with a $30 \mathrm{cc}$ balloon was inserted into the urethra and inflated with an injection of sterile saline. Surgical tubing $(6 \mathrm{~mm}$ I.D.), fastened to a crop strap, connected the catheter outlet to a custom-designed, battery-powered extraction pump placed in a canvas pouch on the left side of the wither harness. The crop strap was $2.5 \mathrm{~cm}$ wide webbing fastened to the wither harness at midpoint and looped snugly around the tail-head. The extraction pump was a 50 -cc syringe housed in a $22 \mathrm{~cm} \times 33 \mathrm{~cm} \times 10-\mathrm{cm}$ aluminum box. The syringe plunger was attached to a screw-driven shaft which would slowly turn and withdraw the plunger from the syringe. The extraction pump was programmed to withdraw a urine sample of 0.5 to $1.0 \mathrm{ml}$ every 10 minutes during the last $12 \mathrm{hr}$ of ${ }^{14} \mathrm{C}$ infusion, when the isotope was in equilibrium with the $\mathrm{CO}_{2}$ pool of the subject. Urine was withdrawn from a 3-cc reservoir fitted to the exposed end of the catheter. All urine flowed through this reservoir and each micturition replaced the volume of urine previously held in the reservoir. An outlet valve at the top allowed excess urine to overflow onto the ground.

Urine samples were analyzed for specific activity following methods outlined by Leng and Leonard (1965). The $\mathrm{CO}_{2}$ entry rate values (where the entry rate was equal to the ${ }^{14} \mathrm{C}$ infusion rate divided by the specific activity of the urine and expressed as grams of $\mathrm{CO}_{2}$ carbon/min) were converted directly to estimates of energy expenditure (kcal.min) using Young's (1970) regression: Energy Expenditure $=1.018+5.178$ Entry Rate.

\section{Laboratory Study}

During August and September of 1980, crested wheatgrass hay was fed to four 260-kg yearling Angus heifers confined in metabolism stalls. The hay was harvested from the Utah Agricultural Experiment Station at Nephi (near the Tintic facility) during early July, 1981. At the time of harvest, the crested wheatgrass was at a hard seed phenological stage of growth. The hay had an in vitro organic matter digestibility (Tilley and Terry 1963) of $47 \%$ and a crude protein content of $5.1 \%$. This hay was fed at rates that provided an intake level of 1.3 (organic matter basis) of body weight, a level similar to that reported by Havstad et al. (1982) for heifers grazing crested wheatgrass rangeland during the summer months.

\footnotetext{
'Harvard Apparatus Company, Inc., Mills, Massachusetts.
}

Estimations of maintenance energy expenditure were obtained during a 10-day digestion balance trial; following a 48-hour fast, estimations of fasting metabolism were obtained. Both estimations were obtained using CERT methodology outlined above with the exception that ${ }^{14} \mathrm{C}$ infusion rates were increased to $100 \mathrm{nCi} / \mathrm{min}$. This increased infusion rate improved the accuracy of the laboratory analysis. Additionally, urine extraction pumps were not used. Instead, all urine excreted by the animal flowed into individual 20 -liter plastic containers. The $\mathrm{Co}_{2}$ entry rate was calculated from the specific activity of urine samples collected during the final 12 hours of the ${ }^{14} \mathrm{C}$ infusion period. One hundred twenty-five $\mathrm{ml}$ of urine from the collection was kept for ${ }^{14} \mathrm{C}$ analysis.

\section{Statistical Analysis}

One-way analysis of variance was used to test for significant $(P<0.10)$ differences in levels of available forage among periods. Analyses resulting in significant $F$-statistics were tested for mean differences using Least Significant Difference statistic (LSD) Steel and Torrie 1960). Confidence intervals $(P<0.20)$ were computed for estimates of energy expenditure.

Table 1. The available forage (AF, $\mathrm{kg} / \mathrm{ha}$ ) and daily energy expenditure (DEE, $\mathrm{kcal} / \mathrm{kgBW}^{75} / \mathrm{day}$ ) of heifers grazing crested wheatgrass rangeland for 5 dates, 1979.

\begin{tabular}{llllllll}
\hline \hline & $6 / 27$ & $7 / 18$ & $8 / 1$ & $8 / 15$ & $8 / 29$ & $X$ & $\mathrm{CI}^{3}$ \\
\hline $\mathrm{AF}^{1}$ & $880^{\mathrm{A}}$ & $762^{\mathrm{B}}$ & $481^{\mathrm{C}}$ & $389^{\mathrm{D}}$ & $284^{\mathrm{E}}$ & 559 & $\pm 90^{4}$ \\
$\mathrm{DEE}^{2}$ & 170 & 180 & 155 & 132 & 170 & 161 & $\pm 32.5^{5}$ \\
\hline
\end{tabular}

'Means in this row followed by a different superscript are significantly different at $P \leq 0.10$.

${ }^{2} \mathrm{Means}$ in this row are an average of two estimates and are not significantly different at $P \leq 0.10$.

${ }^{3}$ Confidence Interval of mean of five dates.

${ }^{4} \mathrm{Cl}(P \leq 0.10)$

${ }^{5} \mathrm{Cl}(P \leq 0.20)$

\section{Results and Discussion}

\section{Field Experiment}

Available forage declined from 880 to $284 \mathrm{~kg}$ / ha over the course of the study, while no trend was apparent for energy expenditure (Table 1). The mean daily expenditure for each of the 5 dates was $161 \mathrm{kcal} / \mathrm{kgBW}^{75} /$ day, which had a standard error of 23.5 and a confidence interval $(P<0.20)$ of \pm 32.5 . The daily organic matter intake of these heifers averaged $1.3 \%$ of body weight, was independent of the changes in the quantity of available forage, and has been reported in more detail elsewhere (Havstad et al. 1982). The wide confidence interval of the estimate of energy expenditure was due to failure of the extraction pump to withdraw a urine sample during $75 \%$ of the 40 attempted CERT measurements. Of the 10 successful urine collections, two were obtained from each of the 5 dates. This problem was viewed as purely mechanical in nature. A portable extraction pump was not commercially available at the time of the study. Future use of this technique would require thorough development and testing of a custom-designed device. The problem was circumvented during the laboratory experiment by the passive collection of total urine output. An additional error in the field was due to the failure of the pump to collect an adequate pooled urine sample for the 12 -hr collection period following ${ }^{14} \mathrm{C}$ equilibration during the 10 successful measurements ( 2 per trial period). Corbett et al. (1971) reported a $17 \%$ difference in the specific activity of urine samples collected at 2 -hour intervals. This error associated with seral sampling would be in addition to 7 to $30 \%$ coefficient of variation typically reported by CERT users when the specific activity of the urine is determined for pooled urine samples.

\section{Laboratory Study}

The maintenance energy expenditure for the heifers was esti- 
mated as $111 \mathrm{kcal} / \mathrm{kgBW}^{75} / \mathrm{day}, 6 \mathrm{kcal} / \mathrm{kgBW}^{.75}$ greater than the estimate for fasting metabolism (Table 2). The slightly higher maintenance expenditure was due to energy expended during feed ingestion, digestion, and metabolism. These two values were not significantly different (see confidence interval) and were combined to provide an estimate of $110 \mathrm{kcal} / \mathrm{kgBW}^{75} / \mathrm{day}$. The combined mean had a confidence interval of $\pm 8(P \leq 0.20)$ and a $19.5 \%$ coefficient of variation. This estimate was significantly less $(P \leq 0.20)$ than the mean estimate of $161 \mathrm{kcal} / \mathrm{kgBW}^{.75} /$ day for the free-ranging conditions. These differences in estimates represent a $46 \%$ increase in energy expended by the grazing animal under free-ranging conditions. Lambourne and Reardon (1963) reported a $16 \%$ increase in daily energy expenditure above maintenance of the penned animal for the free-ranging sheep when forage was abundant and a $33 \%$ increase when forage was relatively scarce. Osuji (1974) calculated a 30\% increase for grazing sheep, and Young (1970) and Wallace (1956) have reported $60 \%$ and $50 \%$ increases, respectively for free-ranging cattle.

Table 2. The daily energy expenditure (DEE, $\mathrm{kcal} / \mathrm{kgBW}^{.75} / \mathrm{day}$ ) for restricted heifers unders maintenance and fasting conditions.

\begin{tabular}{lcrcc}
\hline \hline & $\mathrm{DEE}$ & $\mathrm{SE}^{1}$ & $\% \mathrm{CV}^{2}$ & $\pm \mathrm{Cl}^{3}$ \\
\hline Maintenance & 111 & 7.0 & 19.8 & 10 \\
Fasting & 105 & 10.9 & 20.6 & 18 \\
Combined & 110 & 5.7 & 19.5 & 8 \\
\hline
\end{tabular}

'Standard Error

${ }^{2}$ Coefficient of Variation

${ }^{3}$ Confidence Interval $(P \leq 0.20)$

The proximity of $110 \mathrm{kcal} / \mathrm{kgBW}^{.75} /$ day to the true value of maintenance energy expenditure was unknown, although Brockway (1978) reported CERT had a prediction error of less than $\pm 10 \%$. Typically, a value of $81 \mathrm{kcal} / \mathrm{kgBW}^{.75} /$ day is used for estimating the maintenance requirement for the mature animal. For the growing animal, as used in this study, metabolic rates are reportedly much higher. For example, Reid and White (1979) reported a value of $107 \mathrm{kcal} / \mathrm{kgBW}^{.75}$ for 2-year old steers. Rogerson (1960) found a maintenance cost of $103 \mathrm{kcal} / \mathrm{kgBW}^{.75}$ and Webster et al. (1976) reported a maintenance cost of 94 $\mathrm{kcal} / \mathrm{kgBW}^{75}$, both for yearling cattle. The variation in values would be due to differences in experimental conditions and the type of technique used to obtain estimates of energy expenditure.

The observed difference in energy expenditure under freeranging conditions as compared to stall conditions could be attributed to several factors. The energetic cost of eating has been estimated as 0.32 to $0.82 \mathrm{kcal} / \mathrm{kgBW} / \mathrm{hr}$, the upper limit that was reported by Holmes et al. (1978) and a value applicable to an animal consuming a roughage diet. The energy expenditure associated with 9.2 hours of grazing would be a kcal/ $\mathrm{kgBW}^{.75} /$ day. The 9.2 hours of grazing time was derived from an average of 9.2 hours (Scarnecchia 1980), 8.4 hours (Nastis 1979), and 10.0 hours (Havstad 1980). These three values were recorded under similar experimental conditions where heifers grazed diminishing amounts of crested wheatgrass during the summer grazing period. The 32 $\mathrm{kcal} / \mathrm{kgBW}^{.75} /$ day would be $25 \mathrm{kcal} / \mathrm{kgBW}^{75} /$ day more than for the stall-fed animal which spent 2 hours per day eating a similar quantity of feed. Thus, there was a $23 \%$ increase in energy expenditure above maintenance, or $50 \%$ of the total mean increase attributed to free-ranging conditions. This increase was for the act of eating, and did not include the walking and standing activities associated with grazing.

Using a $0.58 \mathrm{kcal} / \mathrm{kgBW} / \mathrm{km}$ (Blaxter 1962) for travel on $2 \%$ slopes, the energetic cost of travel for these heifers was calculated as $9.5 \mathrm{kcal} / \mathrm{kgBW}^{.75} /$ day. This cost was based on an observed average daily distance of $3.9 \mathrm{~km}$ (Havstad 1980). The $9.5 \mathrm{kcal}$ represent a $9 \%$ increase above maintenance and were $20 \%$ of the observed mean increase due to free-ranging conditions.

No time differences were apparent between free-ranging and stall-fed animals for ruminating, standing and lying activities that might contribute to energetic differences. Additionally, since the ambient daily temperatures during the field study were typically between $10^{\circ}$ and $30^{\circ}$, energetic demands of thermoregulation were not considered as contributing to the daily energy expenditure for the grazing animal. Young (1980) indicated that increased energy requirements as a function of temperature were not realized until temperatures declined below $10^{\circ} \mathrm{C}$.

The remaining $30 \%$ of the observed increase in energy expenditure for the grazing animal could not be readily explained. One possibility is that CERT may have failed to estimate accu rately the energy expenditure by the heifers during the field experiment. Another is that he energy expended by the grazing animal includes energetic costs not attributable to ba sal metabolism or daily activities. Searching for food may include physiological mechanisms not accounted for simply by determining the time spent grazing or the distance traveled. It is also possible that the energetic cost of grazing is not linear in relation to the time spent sea rching for food. Estimations of this energetic expense have not been obtained from animals subjected to long grazing periods or sparse forage conditions. All three explanations are probably correct to a degree.

In conclusion, this study suggests that the free-roaming condition contributes substantially, perhaps as much as $40 \%$, to the energy requirements of range cattle. Like daily intake (Havstad et al. 1982), the energy expended by the animal remained independent of the quantity of available forage. However, both a limited sample size and a large coefficient of variation associated with these samples restricted the stability of this conclusion. Technological improvements in CERT methodology as applied to field conditions are warranted for future research on the bioene rgetics of the domestic grazing herbivore.

\section{Literature Cited}

Arnold, G.W., and M.L. Dudzinski. 1978. Ethology of Free-Ranging Domestic Animals. Elsiner Scientific Co. 198 p.

Blaxter, K.L. 1962. The Energy Metabolism of Ruminants. Hutchinson Scientific and Technical, London. 329 p.

Brockway, J.M. 1978. Escape from the chamber: alternative method for large animal calorimetry. Proc. Nutr. Soc. 37:13-19.

Corbett, J.L., D.J. Farrell, R.A. Leng, G.L. McClymont, and B.A. Young. 1971. Determination of the energy expenditure of penned and grazing sheep from estimates of carbon dioxide entry rate. Brit. J. Nutr. 26:277291.

Dwyer, D.D. 1961. Activities a nd grazing preferences of cows with calves in Northern Osage County, Oklahoma. Oklahoma Agr. Exp. Sta. Bull. B-588. $61 \mathrm{p}$.

Graham, N. McC. 1964. Energy costs of feeding activities and energy expenditure of grazing sheep. Aust. J. Agr. Res. 15:969-973.

Havstad, K.M. 1980. The energy expenditure of heifers grazing crested wheatgrass rangeland in west-central Utah. PhD Diss. Utah State Univ., Logan. $89 \mathrm{p}$.

Havstad, K.M., A.S. Nastis, and J.C. Malechek. 1982. The voluntary forage intake of heifers grazing a diminishing supply of crested wheatgrass. J. Anim. Sci. (In press).

Herbel, C.H., and A.B. Nelson. 1966. Species preference of Hereford and Santa Gertrudis cattle on a southern New Mexico range. J. Range Manage. 19:177-181.

Holmes, C., N.A. McLean, and K.J. Lockyer. 1978. Changes in the rate of heat production of calves during grazing and eating. N.Z. J. Agr. Res. $21: 107-112$

Lambourne, L.J., and T.F. Reardon. 1963. Effect of environment on the maintenance requirements of Merino wethers. Aust. J. Agr. Res. 14:272293.

Leng, R.A., and G.J. Leonard. 1965. Measurement of the rates of production acetic, propionic and butyric acids in the rumen of sheep. Brit. J. Nutr. 19:469-484.

Lifson, N., and R. McClintock. 1966. Theory on the use of the turnover rates of body water for measuring energy and material balance. J. Theor. Biol. 12:46-74. 
Malechek, J.M., and B.M.Smith. 1975. Behavior of range cows in response to winter weather. J. Range Manage. 29:9-12.

Nastis, A.S. 1979. Effects of forage a vailability on voluntary intake and feeding behavior of grazing heifers. PhD Diss., Utah State Univ., Logan. $97 \mathrm{p}$.

Osuji, P.0. 1974. The physiology of eating and the energy expenditure of the ruminant at pasture. J. Range Manage. 27:437-443.

Pechanec, J.T., and G.D. Pickford. 1937. A weight estimate method for the determination of range and pasture production. J. Amer. Soc. Agron. 29:894-904.

Reid, J.T., and D.D. White. 1979. Comparative energetic efficiency of farm animals. Arkansas Agr. Exp. Sta. Special Rep. 72. p. 37-48.

Rogerson, A. 1960. The effect of environmental temperature on the energy metabolism of cattle. J. Agr. Sci. 55:359-363.

Scarnecchia, D. 1980. Grazing behavior of Averdeen Angus heifers in response to a diminishing forage supply. M.S. Thesis, Utah State Univ., Logan. $48 \mathrm{p}$.

Steel, R.G.D., and J.H. Torrie. 1960. Principles and Procedures of Statistics. McGraw Hill, N.Y. 481 p.

Tilley, J.M.A., and R.A. Terry. 1963. A two-stage technique for the in vitro digestion of forage crops. J. Brit. Grassl. Soc. 18:104-111.

Wallace, L.R. 1956. The intake and utilization of pasture by grazing dairy cattle. Proc. 7th Internat. Grassl. Cong. p. 134-145.

Webster, A.J.F. 1972. Act of eating and its relation to the heat increment of feed in ruminants. Proc. Internl. Symp. Envir. Physiol.: Bioenergetics. Univ. Dublin, Ireland. July 18-23, 1971. p. 42-48.
Webster, A.J.F., J.S. Smith, R.M. Crabtree, and G.S. Molliom. 1976. Prediction of the energy requirements for growth in beef cattle. Anim. Prod. 23:329-340.

Whitelaw, F.G., J.M. Brockway, and R.S. Reid. 1972. Measurement of carbon dioxide production in sheep by isotope dilution. Quart. J. Exp. Physiol. 57:37-55.

Yamamoto, S., J.A. McLean, and A.J. Doronie. 1979. Estimation of heat production from heart-rate measurements in cattle. Brit. J. Nutr. 42:507513.

Young, B.A. 1970. Application of the carbon dioxide entry rate technique to measurement of energy expenditure by grazing cattle. (In: A. Schurch and C. Wenk (eds.). Energy Metabolism of Farm Animals. Europ. Ass. Anim. Prod. Publ. No. 13. 259 p.). p. 237-241.

Young, B.A. 1980. Effects of cold weather on the beef cow. 3lst annual Montan Nutrition Conference, Bozeman, Ja nuary 29-30, 1980. Montana Agr. Exp. Sta. Res. Rep. 155. p. 86-97.

Young, B.A., and J.L. Corbett. 1972. Maintenance energy requirements of grazing sheep in relation to herbage availability. I. Calorimetry estimates. Aust. J. Agr. Res. 23:57-76.

Young, B.A., A.B. Kerugan, and R.J. Christopherson. 1975. A versatile respiratory pattern analyzer for studies of energy metabolism of livestock. Can. J. Anim. Sci. 55:17-22.

Young, B.A., R.A. Leng, R.G. White, G.L. McClymont, and J.L. Corbet. 1969. Estimation of energy expenditure from measurements of carbon dioxide entry rate. (In: K.L. Blaxter, J. Kielanowski, andG. Thorbek (eds.). Energy Metabolism of Farm Animals. E.A.A.P. Pub. No. 11.522 p. 